\title{
Osmanlı Kanunnamelerinde İslâm Ceza Hukukuna Aykırı Hükümler
}

\author{
III
}

\author{
Doç. Dr. Coşkun ỰÇOK
}

c) Yargıcın takdirine bırakılmış olan cezalar (Tazir):

İslâm ceza hukukunun bazı suçlara değıșmez, belli cezalar tayin etmiş olduğunu gördük. Bu suçlardan başka da daha birçok eylemler vardır ki bunlar da suç sayılirlar, ancak bunlara verilecek ceza yargıcın takdirine bırakılmıștır. Ne gibi eylemlerin suç sayılacağı da fetvalarla tespit edilmeğe çalıșilmıș olmakla beraber bu hususta da' yargıca takdir hakkı verilmiştir. Hadd, Kısas ve Diyet ile cezalandırılamıyan suçlara verilen cezalara «Tazir» adı verilir. Tazir Lûgatta menetmek, engel olmak anlamına gelen «azr»den çlkmadır ve men, engel anlamınadır.

Hadd cezalarını incelerken, suçlunun suçu bir șüphe ile işlemiș olduğunu iddia etmesi ile cezadan kurtulduğunu görmüștük, Tazir'e uyruk olan suçlarda ise böyle bir idđiia dinlenemez. Ayrıca Hadd cezalarına uyruk suçlarda suçlu ikrarından geri dönebilriği halde Tazir cezalarına uyruk suçlarda geri dönemez. Tazir'e uyruk suçlar Hadd'e uyruk olan suçlardaki gibi zamanaşımına da uğramazlar. Hadd cezalarını yalnız. İslâm Devleíi Reisi veya yargıç uyguladığı halde, koca karısına, efendi kuluna, ve baba çocğuna bazı durumlarda Tazir cezası verebilir. Ancak ceza, suç sayılan eylemlerin ișlenmemesi ve işliyenerin nefislerini islah etmeleri için devlet tarafından konulmuș müeyyid̉eler olduğuna göre koca, efendi veya baba tarafindan verilen cezaları hukukî anlamda ceza saymak, kanaatimizce doğru olmasa gerektir.

Kısas ve Diyet yalnız Hakk-i Ademî'yì ihlâl eden suçlara verildiği halde Tazir hem Hakkı Allah'ı hem de Hakk-i Ademî'yi ihlâl eden suçlara verilir. 
Yargulama usulï bakımından yargı belli cezalarda oldığu gibi bağglanmamıstır: Tazir cezası verebilmek için yemin, işitme tanıklı̆̆ı (Sahada ala Şahada), ỉir erkeğin ve iki lradının tanıklı̆̆ yeter. Ilk zamanlarda hukukun diğer alanlarında olduğu gibi Tazir için de yargıçın durușma dışında görüp ișitmiș olduğu șeylere dayanarak hüküm vermesi prensibi kabul edilmiști fakat sonradan bu, yargıçları kötü kulianma yoluna götüreceği düșünülerek reddedildi (1) ve «Ilm-i Kadî medar-i hükm olamaz prensibi» konuldu.

Şimdiye kađar suçlunun sosyal durumu gözönünde tutulmaksızın herkese eșit cezalar verildiğini gördük, halbuki Tazir cezalarında suçular sosyal durumlarina göre dörde ayrilırlar ve cezalar birinci guruptan durdüncü guruba gittikçe șiddetlendirilir. Fikı kitapları bu gurupları şöylece ayırırlar (2) : 1) Eșraf ül-eșraf, fükaha ve ülema gibi kimseler; 2) Eșraf, kariye muhtarları ve tuiccarların kibarları gibi kimseler; 3) Ortahalliler çarşı esnafı ve 4) Așağı tabaka. Birinci guruptan bir kimseye Kadı'nın böyle bir suç ișlemiş olduğunu söylemesiyle o kimse Tazir edilmiș olur. İkinci guruptan olan kimseler Kadı kapısına götürülürler ve orada Kadı kendilerine aynı șeyleri söyler. Üçüncü guruptan olanlar da Kadı kapısına götürülür, Kadı kendilerine aynı șeyleri söyler ve bunlar hapsedilirler. Dördüncü guruptan olanlar ise ayrıca sopa ile Tazir edilirler. Ancak fıkıhçılar burada da yargıca takdir hakkı bırakmakta ve insanların zenginliğinden, dış değerlerinden daha çok iç zenginliklerine ve değerlerine bakmayı tavsiye etmekte ve birinci guruptan üst üste suc iæliyen bir kimseyi en șiddetli șekilde cezalandırabilecekleri gibi dördüncü guruptan șerefli ve iyi niyetli kimselere de az ceza vererek himaye edebileceklerini söylemektedirler. Bununla braber yargıç bu cezalara ek olarak suçluyu utandıracak eylemlerde de blunabilir, msl. suçluya sert söylemek, suçlunun yüzüne abus çehre ile bakmak, kulağını çekmek; yüzünü tokatlamak gibi. Yargıç isterse yalnız bu gibi eylemlerle de yetinebilir. Tazir olarak verilen cezaların miktarlarının Hadd cezalarından așağı olması da gerektir(3); çünkü Hadd cezaları yఓ Kur'an ile yahut da İcma ile(4) tespit edilmişlerdir, bunların uygulanmasını gerektirecek bir suç ișlenmedikçe bu cezalara yetișen veya bunları aşan cezaların yargıç tarafından ve ilmesi mümkün olamaz. Onun için tazir olarak bi: kimseye ancak 3 değnekten 39 değneğe kadar vurulabilir. Cünkü Kazf-

1) Bk. Hoca Emin Efendi zade Ali Haydar: Dürer ül-hükkâm serh-i Mecellet ülAhkâm Ist. 1330. IV., S. 557 v. öt.

2) Bk. Ms!. Dürer Terc. I., 376; Tercüme-i Tahtavî, IV., 378.

3) Bk. Dürer Terc., I., 376.

4) Hadd-i Surb'da olduğu gibi bk. Dürer Terc, I, 376 ve öt. 
de ve Şurb'da kullara uygulanan Hadd cezası 40 değnektir. Uc değnekten aşağı verilen sopa cezasının da tesiri olamıyacağı düșünülerek cezanın en așağı sınırı olarak 3 değnek tespit edilmiștir. Ancak yargıç bir değnekle de cezanın gayesine. varılacağını anlarsa bir değneğe de hükmedebilir. Ebu Yusuf hürlere verilen Hadd'leri esas kabul etmiș ve onun için bir rivayete göre 3 değnekten 79 değneğe diğer bir rivayete göre de 3 değnekten 75 değneğe kadar yargıçın hükmedebileceğini söylemiștir.

Tazir'de, Hadd cezalarında olduğu gibi hükmedilen değnek cezasının suçlunun vücudunun türlü yerlerine dağıtılması gerekmez, çünkü Tazir'de hafifletme salyı bakımındandır, hattâ Tazir'de Hadd'dekinden daha sertçe vurulur. Sopa cezalarında vurulma bakımından en serti Tazir'dedir, sonra zinada sonra șurb'da ve en sonra Kazf'deki gelir çünkü Kazfde suçlunun doğruyu söylemiș olması fakat iddiasını ispat edemiyecek bir durumda bulunması mümkündür.

Tazir olarak verilen cezalardan birisi de sürgün cezasıdır. Bu cezadan Kur'an'da da bahsedilmiştir (5). Ancak bazı yorumcular sürgünden maksadın hapis olduğunu ileri sürmektedirler, çünkü bunlara göre suçluyu bütün dünyadan dıșarı sürmek mümkün değildir, onu bașka bir yere göndermek oranın halkına karşı hürmetsizlik olur, onun için hakikî sürgün ancak hapisle olabilir(6). Hapis cezası da suçlu yaptığına pişman oluncaya veya kendisinde pișman olduğuna dair belirtiler görülünceye kadar devam etmelidir. Buna karş1 hapis cezasının devaminı sınırland1ranlar da vardır, msl. Șafiî Ebu Abdullah Zübeyrî'ye göre bir meselenin aydınlatılması ve tahkiki için sanık ancak bir ay hapsedilebilir, suçlular ise en çok altı ay hapsedilebilirler(7). Fıkıhçlların çoğu suçluların nefislerini islâh etmeleri șahıslarına göre değișeceğinden hapis cezasının s1nırlandırimasinı yerinde bulmazlar.

Ebu Yusuf'a göre Tazir cezası olarak suçluya malî bir ceza verilebilirse(8) de diğer İmamlar birçok yolsuzluklara meydan vereceğini görerek bunu kabul etmemișlerdir, yalnız sonradan gelen bazı fıkıhçılar suçludan ceza olarak bir miktar para veya malın yargıç tarafından alınmasını ve suçlu o suçu işlemekten vazgeçerek nedamet getirince kendisine geri verilmesini kabul etmișler fakat her ne şekilde olursa olsun bu malları yargıcın kendisj için veya beytülmál için alakoymasını menetmişlerdir; çünkü Islâm hukukunđa şerî bir sebep olmaksızın kimsenin malı alınamaz; suçlunun pişman olmıyacağını yargıç anlarsa bu malı

\footnotetext{
5) Bk. Msl. V. Sure 33. Ayet.

6) Bk. Krcsmarik. a. g. e. S. 560.

7) Bk. Maverdi, Elahkâmüssultanive, Fagnan terc. Alger. 1915, S. 505

8) Bk. Krcsmarik. a. g. e. S. 560 ve Ręd ül-Muhtor II!. 246.
} 
münasip gördügu bir yere sarfeder. Ancak sonradan zalimlerin halkın malın haksiz olarak almaların vesile olmasu diye mal alma ile Tazir büsbütün kalçirılmıștır (9).

Tazir cezaları arasında ölüin cezasınm da yer alıp alamıacağı meselesi fıkıhçllar tarafından kcsin bir sonuca bağlanmamıștır. Beızı fıkıhçlar Tazir'de ölüm cezasına da yer vermişlerse de(10) birçok diğer fkıhçılar kitaplarının Tazir bahsinde bu konuya hiç dokunmamıșlatadr (11). Buna karșılık Tazir cezaları arasında ölüme yer verilemiyeceğini ileri sürenler de vardır(12). Fikrimizce ölüm cezasi Tazir cezaları arasında yer almamalıdır, çünkü Hadd cezalarını incelerken bazı durumlarda zina suçlularına ve yol kesenlere ölüm cezası uygulandiğını gördük, Tazir cezalarının miktar yönünden Hadd cezalarını așmaması gerektiğini de söylemiştik, o halde ölüm cezasının Tazir cezaları arasında yer almaması bu prensibin mantıkî bir sonucu olmalıdır. Diğer yandan İslâm dini ve dolayısiyle hukuku ölüm cezasını çokça uygulayan bir hukuk sistemi değildir; kısas olarak uygulanması gereken ölüm cezası bir yana birakılırsa Kur'an'da yalnız yol kesenlere bazı durumlarda ölüm cezası tayin edilmiș olduğu görülür. Sonradan da Hadisler'e dayanılarak irtidad edenlere ölüm tezası verileceği kabul edilmiștir. Hattâ Ebu Hanife bu cezanın yalnız erkeklere uygulanabileceğini, irtidad eden kadınların ise tekrar müslüman oluncaya kadar hapsedilerek her üç günde bir dayakla tazyik edileceklerini kabul etmiştir. Ölüm cezasını bu kadar az uygulamak istiyen bir hukuk sisteminde yargıcın takdirine bırakılmış bir ölüm cezasından bahsetmek yerinde olmasa gerektir. Tazir cezaları arasında ölüme yer veren fıkıhçılar da' esasen misal olarak yalnız zina suçu ișlerken yakalananların yakalıyanlar tarafından bazı şartlar altında öldürülmesini göstermektedirler(13) ki bu hukukî bakımdan bir ceza olmayıp meșru müdafaada olduğu gibi öldürenin cezasız kalmasını gerektirir bir eylem yani «Mubah» bir eylemdir, hattâ zina işliyenlerin öldürülmesinin «Mubah» olup olmadığı hakkında bile fikir anlaşmazlığı vardır(14). Bazı fıkıhçıların Tazir cezaları arasında ölüm cezasına yer vermelerinin bir sebebi de «siyaseten katl»i Tazir ile kariștırmalarından ileri gelmektedir: Islâm hukuku, kimsenin Allah'ın koymuș olduğu cezalardan başka bir ceza ile cezalandırılmamașı prensibini ka-

9) Bk. Tercüme-i Tahtavî IV., S. 379.

10) Bk. Msl. Tahtavî terc., IV., S. 380 v. öt.

111 Bk. Msl. Dürer Terc. I., 376 v. öt, ve Maverdî, a. g. e. S. 504 v. d.

12) Bk. Karcsmarik, a. g. e. S. $56 i$ not 1.

13) Bk. Msl. Tahtavî terc., IV., S. 380 v. öt.

14) Bk. Handwörterbuch des İslâm, Leiden 1941, S. 282. 
bul ettiği halde sonradan zamania bu prensibe uyulmamiọ ve Islẩm Devleti Reisinin, İslâm cemaati için tehlikeli olan kimseleri İslâm hukuku cezalandırmasa bile, devletin ve cemaatin menfaatini gözeterek cezalandırma hakkı olduğu kabul edilmiștir. Bu yeni prensipten «siyaseten katl» adı verilen ve ne yazıktır ki çok uygulanan bir ceza doğmuştur. Ancak bunu Tazir cezaları arasına! almak doğru değilciir: çünkï bu cezayı vermek yargıcın takdirine bırakılmamıș İslâm Devleti Reisinin emrine bağlanmıștır. Msl. bu suretle kalpazanların(15) «Şibh-i Amd» ile adam öldürmeyi âdet edinmiş olanların «siyaseten ölüm cezasına çarptımlmaları kabul edilmistir.

$\mathrm{Bu}$ suretle İslâm ceza hukukunu bitirmiş oluyoruz. Şimdi Osmanlı kanunnamelerinin ceza hükümlerinden incelemek için seçmiș olduklarımızı görelim.

\section{II.- Osmanlı kanunnamelerindeki ceza hükümleri:}

\section{FATIH SUTLAN MEHMED KANUNNAMESI $(16)=$ FK.}

\section{El-fasl ïl-evvel fi'l-zina ve devaiyye:}

1 - Eğer bir kiși zina kılsa șeriat huzurunda sabit olsa ol zina kılan evlï olsa ve dahi bay olursa ki bin akçaya dahi ziyadeye gücü yeterse cerem(cereme) üçyüz akça alına evsat ül-hal olursa kim altıyüz akçaya mallik ola cerem ikiyüz akça alına andan aşağı gücü yeterse cerem yüz akça alına andan dahi aşağı halli olursa elli akça andan așağı ki gayet de fakür ül-hal olursa kurk akça cerem alına.

2.- Eğer zina kılan ergen olursa bin akçaya dahi ziyade gücü yeterse cerem yüz akça alına eğer orta halli olursa altıyïz akçaya gücü yeterse elli akça cerem alına andan aşağı dörtyüze gücü yeterse kırk akça gayet fakir olsa otuz akça cerem alına.

3.- Eğer avrat zina kılsa șeriat katında sabit olsa gani olsa er kanlığın vere orta halli yahut fakire olsa erenler gibi olur, kanlığın vere.

4.- Eğer avratin malı olsa eri kabul eylese köîtehor kanlığın yüz akça vere yoksul oluras elli akça geyet fakir olursa kırk ya otuz akça ceram alına.

5.- Eğer arvat pezevenklik eylese kadı tazir ede ne kadar ma yerahu ağaç bașina bir akça cerem alına.

15) Bk. Msl, Fetava-î Feyziyve. S. 144.

16) Bk. MOG. I., 1921, S. 19. v. öt. 
6.- Eğer zina eden $\mathrm{klz}$ olursa onun ceremi ergen gibi ola azlıkda ve çoklukta ana itibar edeler.

7.- Eğer biregünün evine girse zina kasdine olursa evlü ceremin vere eğer ergen ise ergen ceremin vere ol zina eden gibi yukarı tafsil üzere ki beyan olundu.

8.- Eğer kul karavaș zina kılsa hür ve hürre cereminin nısfın vere âdet cihetince bayağliyın baylıkda ve yoksullukda.

9.- Eğer biregünün avratın öpse yahut dilese yahut yapışsa kadı tazir ede ağaç başına bir akça cerem alına.

10.- Eğer avrat veya kız bana zina kıldın dese er inkâr eylese bu mezkûrların sözlerine itibar olunmaya ere and vereler avrata kadı tazir ede anı ağaca bir cereme alına.

11.- Eğer avrata er ben sana zina kıldım dese avrat münkire olsa avrat and içe ere kadı tazir ede anı ağaca bir akça cerem alına.

12.- Eğer bir kiși zinayı bilse gelip kadıya demese cerem yok amma oğrılığın bilse gelip demese on beş akça cerem alına.

\section{El-fasl ül-sani fi'l-tedarüib ve'l-teșatium ve'l-katl}

13.- Eğer iki kiși biribirine yapıșsa yakasın yırtsa kadı döğsün, cerem yok eğer birbirinin sakalın veya saçın yolsa kadı katında sabit olsa gani olsa cerem yirmi akça fakir olsa on akça alına ve baฐ̧ı yarılıp kan çıksa otuz akça alına eğer kemik çıssa otacılı(17)olsa ol baș yaran bay olup bin akçaya dahi ziyadeye gücü yetse cerem yüz akça alına eğer ikiyüze gücü yeterse elli akça fakir olursa otuz akça cerem alına.

14. - Eğer adam öldürse yerine kısas etmeseler kan ceremi bay olup bin akçaya dahi ziyadeye gücü yeterse dört yüz eğer altı yüze gücü yeterse iki yüz akça andan așağı halli olursa yüz akça ve fakir olursa elli akça alına.

15.- Eğer bir kişi okuyla yahut bıçağıyla ursa yaşlu olup döşeğe düşerse ol uran bay olup bin akçaya dahi ziyadeye gücü yeterse cerem ikiyüz akça eğer orta halli olursa yüz akça eğer fakir olursa elli akça cerem alına.

\section{El-fasl ül-salis fì şurb ül-hamr ve'l-sirkat ve'l-bühtan}

16.- Eğer biregü hamr içse Türk(18) veya șehirli olșa kadı tazir ura iki ağaca bir akça cereme alına.

17) Tabiblik

18) Köylü 
17.-- Eğer kaz ya ördek oğrlasa kadı tazir uraki ağaca bir akça cerem alina.

18.- Eğer koyun veya kovan oğrılasa cerem onbeș akça alına.

19.- Eğer yançak(19) ya destar oğrılasa elin kesmelu olmıya kadı tazir ura ağaç başına bir akça cerem alına.

20.- Eğer sagir oğrilasa elin kesmiyeler gani olup bin akçaya dahi ziyadeye gücü yeterse cerem yüz akça evsat üi-hal olursa elli akça fakir olursa kırk ya otuz akça alına. alina.

21.- Eğer at oğrılasa elin keseler kesmezlerse ikiyüz akça cerem

22.- Eğer biregünün dahlin(20) ve akçasın oğrılasa gani olsa cєrem kırk akça orta halli olursa yirmi akça fakir ül-hal olursa on akça alina.

23.- Oğul atasından ve ata oğlundan kardaș kardașından ya er avratından ya avrat erinden oğrılasa kałı tazir ura ağaç başına bir akça cerem alina.

24.- Eğer biregünün gözün ya dişin çıkarsa kasdile kısas etmeseler gani olsa cerem ikiyüz akça alına evsat ül-hal olursa yüz akça edna halli olursa elli ya krrk akça gayet fakir olsa otuz akça cerem alına.

25. - Sagir oğlancıklar savaşsalar cerem yoktur.

26. - Cacdan (21) oğrılasa oğrıladığın beylik için aialar.

27. - Eğer yabanda sığır veya yond veya koyun bulsalar kıgırtmasalar (22) bay olursa cerem otuz akça evsat ül-hal olursa yirmi akça fakir olursa on akça alına eğer kıgirtsalar 1 sı(23) bulunmasa kadıya vereler kadı saklata kıgirtığından sonra yiterse cerem yok emr-i șer' ne ise öyle ola.

28.- Eğer yoldan geçerken yoğurt ve etmek alsa kadı ödede tazir ede ağaç bașina bir akça cerem alına.

19) Yançak, vancuk veva yancik at zırhı demokir.

20) Tahil, dahil, ekilmis hububat demektir.

21) Coc, cec, temizlenmis, harman verine viğılmıs hububat demektir. Karadeniz kivilannda hamanduki fudig̈a halà sec denmektedir.

22) Kığırtmak, sağırtıp haber vermek demektir.

23) is, sebip demektir; 


\section{KANUNI SULTAN SƯLEYMAN KANUNNAMESI $(24)=$ SK.}

\section{Bab-i Evvel}

\section{Evvel dört fassl üzerine tertip olunup cinayet mukabelesinde olan} cürüm ve siyaset beyanında mevzudur

\section{Beray-i Zina}

Zinaya muiteallik olan ciirmii beyan eyler:

1.- Bir müsiüman zina kılsa' șer'le sabit olsa ve zina kılan evlü olsa bin akçaya daha ziyadeye gücü yeterse üçyüz akça cerime alına ve evsat ül-hal olụp altıyüz akçaya malik olsa ikiyüz akça cerime alına ve andan aşağı dörtyüz akçaya gücü yetse yüz akç̧a cerime alına ve andan aşağı halli olrrsa elli akça cerime alına ve gayetle fakir olsa kırk akça cerime alma.

2.- Ve eğer zina kılan ergen olup bay olsa bin akça ya ziyadeye gücü yetse yüz akçe cerime alına ve orta halli olsa elli akça cerime alına andàn aşağa dört yüz akçaya gücü yetse kırk akça cerime alına ve gayet fakir olsa otuz akça cerime alına.

3.- Eğer evlü müslime zina kılsa șer'le sabit olsa ganiyye olsa gani er kanlığın vere orta halli ve fakire olsa ona göre er kanlığı gibi cerime vere.

4.- Ve eğer zina eden dul olsa anın ceremi ergenler cerimesi gibi ola azlıkdan çoklukdan görüle.

5.- Ve eğer bunun gibi avratı eri kabul eylese köftehor kanlığı yüz akça alına eğer yoksul olursa elli akça alına ve gayetle fakir olsa kırk ya otuz akça cerime alina.

6. - Ve eğer avrat pezevenklik eylese kadı tazir eylese ne kadar vech görürse ve ağaç bașına bir akça cerime alına.

7.- Ve eğer zina kasdine biregünün evine girse evlü ise evlü ceremin vere ve eğer ergen ise ergen ceremin vere yukarı tafsil üzerki beyan olundu.

8.- Ve eğer kul karavaș(25) zina eylese hür hürre cereminin nısfın vere âdet ve kanun mucebince baylık ve yoksulluk itibarınca.

9.- Ve eğer bir kimse biregünün avratin öpse dilese veya yapıșsa kadı tazir ede ağaç bașına bir akça cerime alına,

24) Bk. TOEM, 16. - 19. sayilara ek.

25) Carive demektir. 
10.-- Ve eğer avrat veya kız sen bana zina kıldın dese er inkâr eylese bunların sözüne itibar etmiyeler ere and vereler avratı kadı tazir ede iki ağaç başına bir akça cerime alına ve eğer avrata ben sana zina kıldım deyüp avrat münkire olsa avrata and vereler eri kadı tazir eyleyüp iki ağaç bașına bir akça cerime alına.

11.- Ve eğer bir kiși zinayı bilip kimseye demese cerime yoktur ve illa oğrılığı bilip kadıya demese on akçe cerime alına.

12.- Bu zikr olunan cerayim kâfirden sadir olsa gani kâfirden gani müslümandan alınan cerimenin nısfı ve mutavassit ül-halden orta halli müslümandan alınan cerimenin nısf ve fakirden fakir ül-hal müslümandan alınan cerimenin nisfi alına.

\section{Tedariibe ve tesatüme ve katl-i nefse müteallik olan cerayimi beyan eyler}

13.-- Eğer iki kişi birbirine yapıș̦ip yakasın yırtsa kadı tazir eyliye cerime yoktur ve eğer birbirinin saçın veya sakalın yolup sabit olsa gani ise yirmi akça cerime alına ve fakir ise on akça cerime alına. Bu hususun kanun-i keferede dahi biaynihdir ganiden yirmi akça alına deyu kaydolunmuştur.

14. - Baş yarılıp kan çısa otuz akça cerime alına ve eğer kemik çıksa otacılı olsa baș yaran bay olsa bin akçaya ya daha ziyadeye gücü yetse yüz akça cerime alına altıyüz akçaya gücü yetse elli akça cerime alına fakir olsa kırk veya otuz akça cerime alına.

15.- Eğer adam öldürse yerine kısas etmeseler bin akça'ya ya daha ziyadeye gücü yeterse dörtyüz akça cerime alına ve altıÿ̈z akçaya gücü yeterse ikiyüz akça cerime alına andan așağı halli olursa yüz akça cerime alına gayetle fakir ise elli akça cerime alına.

16. - Ve eğer iki kiși okla veya bıçakla birbirin urup yaralı ve yașlu olup döşeğe düșse uran kişi bay olup bin akçaya ya ziyadeye güië yetse ikiyüz akça cerime alına ve orıa halli olsa yüz akça vere gayetle fakir olsa elli akça cerime vere.

17.- Ve eğer biregünün gözün veya dișin çıkarıp kasdile kısas etmeseler gani olsa ikiyüz akça cerime alına orta halli olsa yüz akça cerime alına gayetle fakir olsa kırk ya otuz akça cerime alına.

18. - Ve eğer (sagir oğlancıklar) savaș etseler cerime almayalar.

19.- Eğer bu zikr olunan kazaya kâfirden sadir olsa vech-i mesfur ïzere müslïman cereminin nisf alına. 
Şurb-i hamre ve sirkata ve gasba ve tasaddiye müteallik olan cerayimi beyan eder

20.- Eğer bir kiși hamr içse kadı tazir edip iki ağaç bașına bir akça cerime alina.

21.- Eğer kaz veya tavuk veya ördek oğrilasa kadı tazir ede iki ağaç başına bir akça cerime alına.

22.- Eğer at oğrılasa elini keseler kesmezler ise ikiyüz akça cerime alina.

23.- Veya nacak veya destar oğrılasa elin kesmeli olmasa kadı tazir ede iki ağaca bir akça cerime alına.

24.- Bu kaziyye küffarda dahi biaynihi caridir.

25.- Ve eğer bị kimse (biregü) nin tahılın oğrılasa gani olsa kırk akça cerime alına orta halli olsa yirmi akça cerime alına gayetle fakir olsa on akça cerime alına.

26.- O Ŏul atasından veya anasından veya ata oğlundan veya kardaș kardașdan veya er avratındam veya avrat erinden nesne oğrilasa kadı tazir eyleye bir ağaç bașından bir akça cerime alına.

27.- Ve eğer yabanda yond ya sığır veya koyun bulsa çağırtmasa bay olsa otuz akça cerime alına evsat ül-hal olsa yirmi akça alına gayet fakir olsa on akça cerime alina ve eğer çağırtsa ısı bulunmasa kadıya teslim ede saklıya sonra zalyi olursa cerime yok emr-i șer' nece ise öyle ola.

28. - Ve eğer kimse yoldan geçerken zulümle etmek veya yoğurt alsa kadı tazir eyleye ağaç bașına bir akça cerime alına kâfirden dahi müslüman cereminin nısfı alına (veche-i mestur üzere).

29.- Ve eğer bir kişinin atı ya katırı ve öküzü ya hımarı ekine girse davar başına beş çomak ưup beșer akça cerime alına.

30.- Ve inek girse dört çomak urup dört akça cerine alına ve buzağı girse bir çomak urup bir akça cerime alına ve koyun girse iki koyuna bir çomak ve bir akça cerime alına.

31. - Ama evvel hüccet edeler hüccet ettikten sonra islemeyüp(26) tavarlarına timar etmiyecek olursa ki tahıla ve terke (27) ye zarar mü.rettep olmuş ola bu veçhile çomaklayıp (ve ceremleyüp) tehdid edeler ve hem lâzım ziyanı tazmin ettireler her kişi davarına tımar ede reayanin terkesine ziyan olmiya.

26) Islemek (!) ehmemivet vermemek.

27) Hububat, mezruat. 
32.- Ve eğer yabanda veyahut köyler arasında veya davar suvadında (28) ekilmiş tahı̣llar olsa davar uğrağina ulağı(29) ederler.

\section{Mücerred sitasetin beyan eder}

33.- Kız ve oğlan çeken kimsenin hiyanet ile bir ecnebinin evine giren kimsenin avrat ve kız çekmeğe bile varan kimsenin içmeği(30) kesile.

34.-- Kız ve avrat çekip güçle nikâh ettirene cebirle boșatıp nikâh edenin sakalın keseler ve muhkem let(31) edeler.

35.- Ve avrat ile tutulanın șer'en siyaseti ne ise icra edeler.

36.- Ve adam öldüren kimesneyi öldürdüğü kimesnenin yerine öldüreler.

37.- Ve esir oğrılayanı ve esir ayardanı ve dükkân açanı ve birkac kez hırsizlığı zahir olmuş kimesneyi asalar.

38.- Ve pezevenklik edenin alninda dağ edeler.

39. - Ve bir bölük halk içinde adam ölse(hırsızlık olsa) tehdid edeler (katili) ve hrrsızı bulduralar bulmazlar ise ol halkı tutup hapsedip dergâh-i muallaya arzedeler ferman-i kaza cereyan anların babında ne veçhile sudur bulursa mucibiyle amel edeler.

40.- Köy içinde veya mahalle içinde adam ölse veya kârban basłlıp hasarat veya bir köy (iki köy veya üç dört pare köy) arasında oğrıllk ve haramilik olsa elbette (edeni) buldurup çıkaralar şöyleki bulmak imkân olmyya diyet salalar (cerimesini) çekeler.

41.- Ve bir kimesnenin evinde veya elinde ogrillk nesne bulunsa satın aldıysa satanı bulduralar bulmazsa (ki) müttehim (ola) işkence edeler meğerki. (bulduğu vakit) getirip kadıya teslim ede veyahut yabanda bulduğun ispat ede ama işkencede ihtiyat edelerki kabl el-sübut telef-i nefs olmıya ve eğer işkenceden ölürse davası sorulmıya.

42.- Ve yan kesenin ve adam bıçaklıyanın eğer bıçaklamak âdeti ise elin keseler eğer âdeti değil ise kollarına biçak sancub gezdüreler.

43.- Eğer bir kiși atasın veya anasın veya akrabasın öldürse emr-i șer' nice ise öyle ola.

28) Suvad, Sisad (!) kovunların sulandiğı ver.

29) Ulağı veva Avlağu bir verin korunması için etrafına çekilen çit.

30) Kanunnameyi yayınlayan Mehmet Arif bey bu kelimeyi anlıyamadığını bunun belki de dizin alıındaki kemik demek olan «incik» demek olduğunu sōylüyor (!).

31) Let etmek dög̈mek demektir. 
44. - Şehirlerde ve köylerde olan evlere od korlar ufak tefek esbab yanar şer'le sabit olmayıp bir kimesneye töhmet etseler tehdid ile (edeni) bulduralar eğer kasdile etmiş ise asalar ve bile gelenlere yasak edip ilden süreler.

45.- Ve eğer örf ile bir kimesnenin hırsızlığı zahir olur ise kadı olan ehl-i örfe hüccet verip ehl-i örf ol hüccet mucebiyle asılmağa müstahak olanı asa ve kat'-i uzva müstahak olanı kat'-i uzv edeler kadı bu babda mani olmiya ve siyasetin tehir ettirmeyip günah olan yerde ettire.

46.- Ve hirsız tayıfası işkencede ikrar etse ve alaim dahi delalet etse ol ikrar muteber ola.

47.- Eğer hırsız malûm olup ol dahi bir kimesne için şerikimdir dese ve ol kimesne levend ve müttehim ise işkence edeler eğer müttehim değil ise mücerred hırsız sözüyle işkence etmiyeler.

\section{BOSNA KANUNNAMESI $(32)=$ BK.}

1.- Eğer müslüman hamr sıksa veya bey' eylese kadı tazir edip iki ağaca bir akça cerem alına eğer bir kimesne hamr içse kadı tazir edip iki ağaca bir akça cerem alına.

2.- Ve dahi yalan șehadetin edenin ve tezviri hüccet verenin muhkem hakkından geleler ve șuhud zor tazir edip teșhir edeler.

3.- Ve tezvir ve telbis zahir olanı muhkem hakkından gelip alnına damga basalar.

4.- Ve tezviri hüccet yazanın âdeti ise elin keseler değil ise muhkem hakkından geleler.

5.- Ve dahi iddet tamam olmadan nikâh eden kimesnenin muhkem hakkindan geline.

6. - Ve dahi binamazı mahalleye teftiş edip muhkem tazir edip ik」 ağaca bir akça cerem alına.

\section{MEHMED KANUNNAMESI $(33)=$ MK.}

1.- Bir kimseye töhmet isnad olsa oğluna ve karındașlarına ve akrabasina ve küfelasına ve ehl-i kariyesine ve mahallesi cemaatine veya evinde sakin olduğu kimseye teklif edip bulduralar.

32) Glasnik Zemaliskog Muzeva u Bosni i Hercegovini, XXVIII., 1916, 3/4. S. 448-450. Bu kanunnamedeki hükümlerin çoğu Süleyman Kanunnamesinin aynı olduğu için valnız 0 kanunnamede bulunmuvan hükümleri burava aktardik.

33) Bk. Ahmed Lutfî: Mirat-i Adalei. S. 78 v. st. 
2.- Ve dahi bir yerde derbend muhafizları olup hifizda kusur ve tekâsül etseler ebnay-i sebilin ol yollarda zayi olan şeylerini alanı bulmazlarsa anlara tazmin ettireler zira derbendi hıfz üzerlerine lâzımdır.

3. - Kaza ve tedris ve tevliyet ve meşihat ve imamet ve hitabet ve bunun emsali menasib ve cihet sahiplerine tazir lâzım gelse etmiyeler hemen bir dahi böyle etme deyu kadı anifle söylemek ol makulelere tazirdir ve hapsedecek yerde etmeyip dergâh-i muallaya arz edeler meğerki şenaat-i azîmi eyleyüp kefil bulmayıp firar ihtimali olsa ol-vakıt hapsedeler.

4.- - Bir kimse için hırsız bakiyedir deyu mahalle veya kariye cemaati şikâyet edip red ve tard etseler filvaki ol kimsenin töhmeti beynülnas maruf olsa mahallesinden ya kariyesinden rededip süreler eğer vardığı yerde dahi kabul etmezlerse șehirden süreler ama bir kaç gün tevkif ede belki tövbe ve istifar ile islah-i nefs eyler eylemez ise süreler.

5.- Ve esir oğriliyan ve esir ayardan ve dükkân açan ve bir kaç defa hrssızlığı zuhur eden kimseler siyaseten salb edile.

6.- Pezevenklik edenin alnına dağ edeler.

7.- Yan kesenin âdeti ise elin keseler değil ise siyaseten teșhir edeler.

8.- SSehirlerde ve köylerde evlere od koyup ihrak edenler kasdile olduğu șer'le sabit olursa salb edeler.

Bu kanunname hükümleri gözden geçirilince her șeyden önce cezaların tayininde suçluların malî durumlarına göre sınfflara ayrıldıkları göze çarpmaktadır. İslâm hukukunda, tazir cezalarının uygulanmasında suçluların sosyal durumlarına göre dörde ayrıldiklarını ve en yüksek sosyal durumda olan suçluya en az ceza verildiğini, buna karșsllkk Hadd, Kısas ve Diyet cezalarında suçlular arasında ne malî bakımdan ne de sosyal bakımdan bir tefrik yapılmadığını yalnız burada suçluların kadın veya erkek ve hür veya kul olmalarının cezaların tayininde bazı tesirleri olduğunu görmüștük. Osmanlı kanunnamelerinde suçlulaıın malî durumlarına göre yapılan ayrımın gayesi İslâm ceza hukukunda Tazir'de yapılan ayrımın tam aksinedir: Burada malî durumu en yükssek olan suçlu en ağır cezaya çarptırılmaktadır ki bu da bugünkü malî ceza telâkkilerine çok uygundur. Kanunnamelerde suçluların malî durumlarına göre böylece ayrılmaları İslâm ceza hukukuna aykırıdır, kaldı ki kanunnamelerin birçok hükümleri ile tespit edilmiş olan malî cezalar, zarar gören yana ödenen bir nevi tazminat demek olan Diyet cezasindan bașka malì ceza tanımıyan ve Tazir cezaları arasında mali cezalara yer ver- 
mek istemiyen İslâm ceza hukukunun esas prensiplerine tanamiyle aykırı düşmektedir.

Bu malî cezaların şer'î cezaların tamamen yerini mi tuttuğu yoksa bunların bir nevi fer'î cezalar mı olduğu kanunname hükümlerinin çoğundan anlașlamamakda ise de bazı hükümlerde(34) bu cezaların șer'î cezaların yerini tuttuğu açıkça görülmektedir.

Şimdi hükümleri ayrı ayrı gözden geçirelim:

FK.nin 1.-4., 6. ve 8. maddeleri ile SK.nin 1.-5. ve 8 . maddeleri zina ve zinanın muhtelif nevileri hakkındaki hükümleri tespit etmektedir. FK. 1 ile SK. 1 genel mahiyette zinayı hükme bağlamaktadırlar. Bu iki madde arasında iki fark vardır: FK. 1'de üçüncü gurubun malî kudreti tayin edilmemiș olduğu halde SK 1'de bu 400 akçe olarak gösterilmiștir. Bir de FK. 1'de bu cezalar bütün İslâm devleti uyruklarını tehdit eder göründüğü halle SK. 1'de bu cezaların yalnız müslüman olan suçlular için tespit edilmiş olduğu görülmektedir. Bu ikinci fark her iki kanunnamenin diğer maddelerine de teșmil edilebilir çünkü SK. 12 ve 19'da müslüman olmıyanlar için daha hafif cezalar tayin edilmiș olduğu görülmektedir. Her iki kanunnamenin 1. maddelerini teșkil eden bu hükümler ile İslâm ceza hukukunda, zina işliyenlere verilmesi kabul edilmiș olan recm veya sopa cezalarının kaldımılmış olup olmadığ anlaşılamamakda ise de suçun ispati bakımından Islâm ceza hukukuna sałlı kalındığı açıkça görülmektedir.

FK. 2 ile SK. 2 arasında hiçbir fark yoktur bu maddeler bekârların (ergenlerin) zinadan ötürü çarpılacakları cezayı göstermekteḍir, yalnız FK. 1 ve SK. 1'de suçlular malî durumlarına göre beșe ayrıldıkları halde bekârlar dörde ayrilmaktadırlar.

FK. ve SK. 3'de evli kadınların da evli erkekler gibi ceza görecekleri tespit edilmiștir. Her nekadar FK. 3'de kadınların evli olacakları yazılı değilse de 6'da zina eden kızların bekârlar gibi ceza görecekleri yazılı olduğuna göre FK. 3'ün evli kadınları hedef tuttuğu amlașılmaktadır. SK. 4'de dul kadınların bekârlar gibi cezalandırılacakları yazılı olduğu halde bu kanunnamede kızların zinasından bahsedilmemiștir. Buna karșılık FK. 6'da kızların bekârlar gibi cezalanđırılacakları söylenmiş fakat bu kanunnameye de dullar hakkında bir hüküm konulmamıștır.

FK. 8 ile SK. 8'de zina eden kulların, hürlerin yarısı kadar para cezası ödiyecekleri ve bu sırada kulların da malî durumlarının (35) göz

34) Bk. MsI. FK. 21 , SK. 22

35) Baylikda ve yoksullukda; baylık ve yoksulluk itibarınca. . 
önïnde tutulacağ yabılıdır. Ancak kulların hukukî kişiliği olmadığına göre onların malî durumlarından da bahsedilemiyeceğinden, bu cezaları efendileri mi ödiyecektir, kim ödiyecektir bu belli olmamaktadır.

FK. 4 ile SK. 5'de de evlerine erkek kabul eden kardınların çarpılacaklar ceza gösterilmiștir: Bunların zengin olanları 1000 akçe «Köftehor kanlığı»(36) vereceklerdir. Kanunnamelerin bu hükümlerinden bu gibi suçluların, evli zira suçluları ile bir tutulmaaıları dul veya kızlarlá eșit oldukları görülmektedir.

SK. 35'de «Avrat ile tutulan»dan bahsedilmekte ise de yukarda incelediğimiz maddelerde șeriat katında sabit olan zina suçları hükme bağlanmıștır; SK. 35 ise zina sayılmıyacak bir şekilde «Avrat ile tutulan» erkeğe ne yapılacağını göstermektedir. FK. ve SK. 7'de de zina kasdi ile bir eve girenler zina edenlerle bir tutulmuşlardir. Bunlar evli veya bekâr olduklarına göre evli veya bekâr zanilerin ödiyecekleri cezaları ödiyeceklerdir. Buna karşlık başka birisinin karısına sarkıntılık edenleri cezalandırmayı kanunnameler «Tazir» sınırlaırı içinde yargıca bırakmıșlardır(37); yalnız burada da Tazir ile birlikte gene para cezasına rastlamaktalyız: Yargıç hükmettiği her ağaç bașına bir akça da para cezası alacaktır. Bunun gibi pezevenklik eden kadınlar da Tazir ile cezanlandırılıp ağaç bașına bir akça para cezası alınacaktır (38). SK. 38 ve MK. 6'da da pezevenklik edenlerin alınlarına dağ vurulacaktır yazılıdır. FK. 5 ve SK. 6 'da bu suçu ișleyen kadınlardain bahsedildiğine göre SK. 38 ile MK. 6'daki hüküm yalnız erkekleri hedef tutmuș olmalıdır. $\mathrm{Bu}$ hükümlerle konulmuş olan «alna dağ vurma» cezası ise İslâm ceza hukukunun hiçbir yerinde tesadüf edilemiyen bir cezadır; Tazir cezalarının çeşitlerini sayan fıkıh kitáplarında böyle bir ceza bulunmamaktadır, bu itibarla bu ceza İslâm hukukunun yabancısı olđuğu bir cezadır diyebiliriz.

FK. 10 ve 11 ile SK. 10'da zina iftirasının bir nevi hükme bağlanmıştır: $\mathrm{Bu}$ maddelere göre bir kadın veya kız bir erkeğe sen bana tecavüz ettin dese ve erkek inkâr etse erkek yemin edecek ve cezadan kurtulacaktır, kadın veya $k 1 z$ ise tazir edileceklerdir. Eğer bir erkek bir kadına ben sana tecavüz ettim dese ve kadın inkâr etse kadın yemin ederek kurtulacak, erkek ise tazir edilecektir, ayrıca FK.ne göre her ağaç bașına bir akçe SK.ne göre de her ağaç bașına iki akça para cezası

36) Köftehor kanlığının ne olduğu anlaşılamamıştır. Kraelitz-Greifenhorst Köftehor'u geric anlamina almaktadir. Bk. a. g. e. S. i9. v. öt.

37) Bk. FK. ve SK. 9.

38) BK. FK. 5 we SK. 6. 
alınacaktır. Her iki kanumnamenin bu hükümleri gerck ceza gerek usul bakımından İslâm hukukundan ayrılmaktadırlar. İslâm ceza hukukuna göre zina iftirası (Kazf) nın hürlerde 80 değnek kullarda ise 40 değnekle cezalandırıldığını ve bu cezanın değișmez bir ceza, bir Hadd cezası olduğunu görmüștük. Bu hükümler ile zina iftirasında bulunanların cezası yargıcın takdirine bırakılmıș yani «Tazir» sınırları içine sokulmuş olmaktadır. Usul bakimınından da zina iftirasının var sayılabilmesi için zina isnat eden kimsenin isnadını dört erkek tanıkla ispat edememesi gerektiği halde burada iftiraya uğrayanın yemini zina iftirasının sabit olmasına yeter görülmüştür.

FK. 12 ile SK. 11'e göre zina suçunun ișlendiğini bilip te yargıca haber vermiyen kimseler cezalandırılmazlar halbuki hırsızlığı bilip te haber vermiyenlerden FK.ne göre 15 akçe ve SK.ne göre 10 akça para cezasi alinir.

Zina ve zina iftirası hakkındaki hükümlerden en ilgiyi çekeni hiç şüphesiz ki FK.nde bulunmıyan SK. 12'nin hükmüdür. Bu maddeye göre şimdiye kadar incelediğimiz suçları Zimmîler ișlerse bunlar müslümanların ödemeğe mecbur olduklarının yarısi kadar para cezasına çarptırılacaklarıdır. FK.nin hiçbir yerinde Müslümanlarla Zimmîler ayırtedilmedikleri halde SK.nin dört ayrı maddesi(39) ile Zimmîlere uygulanacak ceza gösterilmiștir: SK. 19'da dövme, yaralama ve öldürmeden ötürü de Zimmîler'in yarı cezaya çarptırnlacakları tespit edilmiştir. Hursızlık ve saç sakal yolmada ise Müslümanlarla Zimmîler eşit tutulmuşlardır(40). FK.nde Zimmîleri Müslümanlardan ayıran hükümlerin bulunmayıșı bu ayrımın Fatihten sonra yapılmış olduğunu bize göstermektedir. Para cezası bahse konu olduğu bir sırada bazı suçları işliyen Zimmîler'in aynı suçlam işliyen Müslümanlardan daha az cezaya çarptırılmalarının sebebini anlamak kolay değildir. Ceza, suç işliyen insanların nefislerini islah etmeleri ve suç işlemek istiyenleri bundan men için konulmuş olduğuna göre devletin bazi uyruklarını diğerlerinden böyle daha az cezalarla tehdit etmiş olmasının sebebi ne olabilir? İslâm dini ve İslâm devleti hakim olduğu ülkelerde Müslüman olmıyanları kendi din, örf ve âdetlerine göre yașamakta serbest bırakmıș, doğrudan doğruya kendi bünyesine aykırı gelmiyen kurumlarına dokunmamsștır, onun için zina ve zina iftirası gibi dinî mahiyet tașıyan ve Allah'a karșı ișlenmiș sayılan suçlardan Zimmîlerin ilerde öbür dünyada nasıl olsa cezalandırılacaklairı düşünülerek daha az bir cezaya uyruk tutulmuş olmaları akla

39) Bk. SK. 12, 13, 19., 24.

40) Bk. SK. 13, 24. 
gelebilir. Belkí de devlet Müslüman uyruklarından daha cook para cezasi almakla onlara, Allah'a karșı suç iṣlemek yolunda, Zimmîlerden daha büyük engeller koymak istemiștir. Ancak gene Allah'a karşı iş̧lenen suçlardan olan hirsızlıkta ise Zimmîlerle Muslümanlar arasında bir ayrım yapılmamıștır. Buna karșllı insanlara karșı ișlenen suçlardan yalnız saç sakal yolmada bütün uyruklar eșit tutulmuş, dövme, yaralama; öldürme gibi suçlarda ise Zimmîlere gene yarı ceza tayin edilmiștir ki eğer hüküm bir Zimmînin diğer bir Zmmîyi öllürdüğü, yaraladığı veya dövdüğü durumları hedef tutmuyorsa buna makul bir sebep bulmak çok güçtür.

FK. 13,$15 ; 24 ; 25$ ile SK. $13 ; 14 ; 16 ; 17 ; 18$ döğüşme ve yaralama hakkında hükümler ihtiva etmektedir: Birbirleriyle yalnız yaka yirtacak kadar dövüşüp yaralamaya veya sakatlamaya kadar varmıyanlar doğrudan doğruya, bildiğimiz gibi; yargıcın takdirine göre Tazir ile cez\&landırılırlar. Birbirlerinin saç veya sakalını yolanlardan ise para cezası alınır, ancak burada suçlular diğer suçlarda olduğu gibi malî durumlarına göre üçe veya dörde değil zengin ve fakir diye ikiye ayrılmıșlardır (41). Baş yarılıp kan çıkması hallerinde ise bütün suçlular malî durumları gözönünde tutulmadan aynı para cezasını ödiyeceklerdir. Baş yarılıp, kemik çıkıp tabibe ihtiyaç olmasında... ise suçluların gene malî durumlarına göre ayrıldıkları görülmektedir(42). Okla ve bıçakla yaralamada da suçlular aynı șekilde ayrılmaktadırlar(43). Göz veya diş çıkarma gibi Kısasla cezalandırılan suçlarda suçluya kısas uygulanmadığı takdirde kendisinden gene malî durumuna göre para cezası alnnmaktadır. Ancak her iki kanunname metnindeki «Kasdile Kisas etmeseler»(44) tabirinden maksadın ne olduğu iyi anlaşllamıyor. Bundan maksat zarar gören tarafın Kısas istemeyip Diyet istediği durumlar ise o zaman, zarar görene veya varislerine verilen bir nevi tazminat demek olan Diyet'le beraber ayrıca devlet lehine para cezasına hükmolunacak demektir. Yok yargıçı' Kısas uygulamak istemediği bir durum anlatılmak isteniyorsa, o zaman yargıça Kısası uygulamak veya uygulmamak hususunda da takdir hakkı verilmiș ve Kısas cezasının yerine sırasına göre para cezası konulmu; olur ki bu zarar göreni Diyet almak hakkından mahrum etmek demektir. Tanzimat'dan sonra çıkan ilk ceza kanunları ile bile zarar görenlerin bu hakkına dokunulmamıș olduğu gözönüne alınırsa bu tâbirle birinci ihtimalin anlatılmak istenmiş olduğunu kabul etmek gerekir. Nitekim

$41\}$ Bk. FK. ve SK. 13.

42) BK. FK. 13. ve SK. 14

43) BK. FK. 15. SK. 16.

44) BK. FK, 24, SK, 17. 
FK. 14 ile SK. 15'de adam öldürünce Kısas uygulanmazsa kan cerimesi olarak malî dưrumuna göre para cezası hükmedilmesi emredilmiștir. Demek ki Diyet cezası ile birlikte Islâm ceza hukukuna aykırı olarak bir de para cezası kabul edilmiștir. $(1)$

FK. 16 ile SK. 20 ye BK. 1'de șarap içenler ve yapip satanlar için ceza tayin ediImiștir. Şarâp içmenin İslâm hukukunda Allah'a karș̣ ișlenen suçlar arasında yer aldığını ve bunun için tayin edilmiş olan Hadd cezasının da 80 değnek olduğunu görmüstük. Kanunnamelerin bu hükümleri ile bu Hadd cezası yerine yargıcın takdirine bırakılmış Tazir cezası ve hükmedilecek her iki sopa için ayrıca bir akça para cezası konulmus olduğu görülmektedir. BK. 1'de ayrica șarap yapan ve ssitan Müslümanların da aynı cezaya çarptırılacakları yazılmıștır $k i$ bu suretle bu kanunnameye göre șarap yapmakla satmak ceza bakımından șarap içmekle eșit tutulmuștur. Zimmîlerin şarap yapıp satmalar ve içmeleri serbest olduğuna, hattâ bunlardan vergi olarak alınan şarapların Dirlik sahipleri tar̀afından satılabilmesi için «Monopolye» ilân edildiğine göre kanunnamelerdeki «biregü», «bir kiși», «bir kimesne» tâbirlerinin de «bir Müslüman» diye kabul edilmesi gerekir. Hattâ bu bakımdan SK. 24 'deki «Bu kaziyye küffarda dahi biaynihi caridir» hükmünün 20 numaralı hükmü kapsamamıs olması gerekir.

FK. 17.-23., 26. ile SK. 21.-26., 37, 45.-47. ve MK. 4.-5.'te hırsızlığa ait hükümler tespit edilmiştir: Hırsızlık için tayin edilmiş olan cezalar çalınan şeyin cinsine göre değișmektedir. Islâm ceza hukukuna göre değeri 10 gümüş dirhemi geçen malları çalan kimselerin elleri kesildiği halde, kanunnameler bazı malların çalınmasısında değerlerine bakmaksızın Tazir ve sopa başına bir akça(45) veya iki sopa başına bir akça para cezası (46), bazı mallarda ise malî durumlara göre belli para cezaları(47) bazı durumlarda da malî duruma bakılmadan belli para cezalam(48) tayin etmișler ve bazı durumlarda bir Hadd cezası olan el kesmeyi açıç̧a menetmişler(49) diğer bazı durumlarda el kesmek veya Tazir ile sopa bașına para cezası almak (50) veya doğrudan doğruya belli para cezası almak yolunda yargıçı serbest bırakmıșlardır(51).

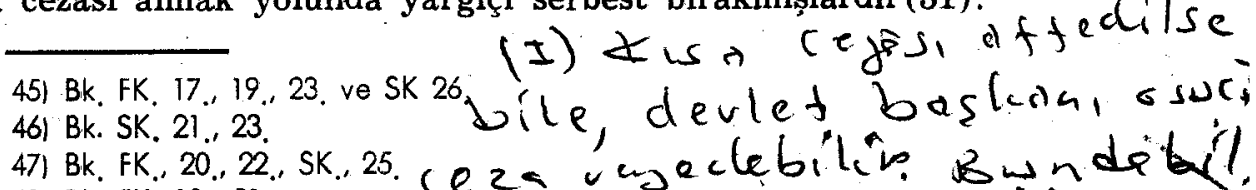

48) BK. FK. 18, 21.

49) Bk. FK. 19.

50) BK. SK. 23.

51) FK. 21, SK. 22.

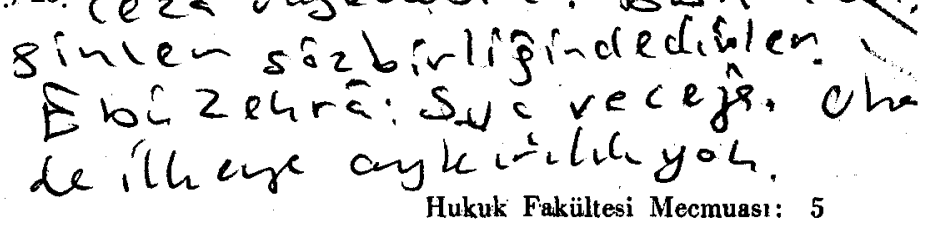


İslâm ceza hukukuna göre ergin olmıanların ișledikleri suçlar cczalandırılmadığı halde FK. 20 'de ergin olmiyanların işledikleri hırsızlık suçlarına malî durumlarına göre para cezası tayin edilmiștir. Gene İslâm hukukuna göre yakın hısımlärin birbirlerinden mal çalmaları hırsizlık sayılmadığı ve bu itibarla cezalandırılmadığı halde(52) burada bu, suç sayılarak Tazir ve para cezası ile cezalandırılmıștur (53).

Hirsızlığa ait hükümlerin en ilgi çekeni FK.nin 26 numaralı hükmüdür. Bunal göre «cacdan» yani harman yerine yığilmıș temiz hububattan bir miktar çalınırsa bu «Beylik» için müsaedre edilecek, yani çalınan mal sahibine geri verilmiyecektir. Böylece, herhalde «cac»mi muhafaza etmiyenler de cezalandırılmak istenmiş olsa gerektir.

SK. 37 ve 45 ile esir hrrsızları ve esir ayartanlarla, dükkân açanlara ve bir kaç kere hirsızlık edenlere en büyük ceza olan idam cezası tayin edilmiștir. İslâm ceza hukukunda ölüm cezasının çok mahdut hallerde verildiğini görmüștük, bu hükümlerle Islâm hukukunda sonradan kabul edilmiş olan Islâm devleti reisinin «Siyaseten katl» hakkına dayanılmıştır. Ancak «siyaseten katl»de yainız Islâm hukukunun boş bırakmıș olduğu hususlarda uygulanmak gerekirken bu hükümle Hadd cezası ile cezalandırılmıș olan hırsızlı suçunun bazı nevileri için tespit edilmiş oluyor. Meselâ Şibh-i 'Amd ile adam öldürmeyi âdet edinmiș olan kimseler için İslâm ceza hukukunda her defasinda yeniden Diyet ödemekten başka ceza olmadığ için bu gibi suçluların «siyaseten katl»i kabul edilmiştir, halbuki birkaç kere hırsızlık edenler için tayin edilmiş, el kesme, ayak kesme ve nihayet tövbe edinceye kadar hapis gibi belli cezalar olduğuna göre burada da «siyaseten katl»e bașvurulması hem Islâm hukukuna hem de sonradan kabul edilmiṣ olan «siyaseten katl» prensibinin kabul sebeplerine aykırıdır.

MK. 4'de de hırsizlığı ile tanınmış olanlara, haklarında mahalle veya köy halkı tarafindan şikâyet vaki olduğu taktirde, sürgün cezası tayin edilmiștir, ancak kendilerine nefislerini islâh için de bir kaç gün mühlet verilmiștir.

SK.nin 41,46 ve 47 numaralı hükümleri ise hırsızllk bahsinge usulii ilgilendirmektedir: Elinde veya evinde çalınmış mal bulunan kimse bu malı satın almıs oldığunu veya yabanda bulduğunu ispat edemezse sanık sayılacak ve işkenceye maruz kalacaktır, işkencede suç sabit olmadan sanığın ölmemesine dikkat edilecektir, ișkenceden ölen sanıkların ölü-

52) Bk. Yukarda C. III. Sayı I. S. 142.

53) BK. FK. 23., SK. 26. 
münden zarar görenler ise dava açamıacaklardu. Samı̆ın suçu işlediğine dair deliller varsa ve işkence strasurida ikrar etmisse bu ikran makbul saylacaktir. Hadd cezalarma uyruk suçlarda tankla ispat e lilemiyen suçların ancak sanı̆̆ın ikrarı ile sabit olacağını ve suçlunun ikrarından da dönebileceğini görmüștük, buna karșilik kanunnamenin işkence ile sanığ ikrara mecbur etmesi ve bunun gibi hursızin șerikimdir dediği kimselerden töhmet altında olanlarına dà ișkence edilmesini emretmesi usul bskimindan İslâm ceza hukukuna aykur diismektedir.

SK. 42 ve MK. 7 ile yankesicilere ceza ayin edilmi,tir. Yankesicilik de bir nevi hirsizhk olduğuna göre hrrsizhk için konulmuş olan Fadł cezası ile cezalandrilmak gerekirken kanunnamelerin bu hükümleri ile yankeşiciliği âdet edinenlerin elleri kesilecek, bir defa iṣliyenler ise teshir edileceklerdir.

SK. 42'deki «adam biçakliyanın eğer biçaklamak âdeti ise»den maksat da herhalde Kısas'a uyruk olmıyacak șekilde adam yaralamayı âdet edinen kimseler olsa gerektir.

SK. 44 ile MK. 8'de Islâm hukukunda belli cezalarla teyid edilmemiș olan bir suç için ceza táyin edilmiştir: Buna göre kasitle kundakçlhk yapanlar aslacaklar ve șerikleri de(54) sürüleceklerdir.

SK. 40'da İslâm ceza hukukunda «Kasame». adı verilen kollektif cezanin kabul edilmiș olduğunu görüyoruz. Ancak bu ceza köyler arasinda işlenen hirsızlik ve yolkesicilik suçlarına da teşmil edilerek bu suretle burada da bir yenilik yaplmıștır. SK. 37'de de belli bir miktar insan arasında birisi öldürülse veya hirsızlık olsa öldüren veya hursız bulunmazsa «Dergâh-i Mu'alla»ya sorulması ve gelecek emre göre hareket edilmesi emredilmektedir.

SK. 33'de kız ve oğlan kaçıran, kaçırmaya tessebbüs eden ve kötü niyetle bir başkasının evine girenlerin cezası tespit edilmiștir. Kız ve oğlan kaçirma ve basşkasının evine girme Islâm ceza hukukunda belli bir ceza ile cezalandrrılmadı̆̆ına göre Tazir ile cezalandırılmak icabeder, halbuki kanunnamede bunların «içmeği» $(55 \overline{)}$ nin kesileceği yazlıdır. Eğer «çelmeğe bile varan» tâbirini «Teşebbuis eden» díye kabul edecek olursak, burada İslâm ceza hukukunda cezalandırımıyan suça teşebbüsün de cezalandırımış olduğunu görürüz.

Kız ve kadin kaçırıp zorla nikâh ettirenlerin cezası ise bu kız veya kadinı zorla boșamaları, sakallarınin kesilmesi ve dövülmeleridir (56).

54.: Bile gelenter

55) Bk. Not 30 .

56) Bk. SK. 34. 
Bunun gibi bekleme müddeti bitmeden bir kadını nikâhlıyanlar da cezaya çarptırilırlar (57).

BK. 2'de gördüğümüz yalan yere tanıklık hakkındaki hüküm Islâm ceza hukukuna liygundur ancak aynı kanunnamenin 3 numaralı hükmünde gördügümüz «alna damga basmak» ve 4 No.daki «el kesmek»cezalarından birineisi maahiyet bakımından ikincisi ise uygulandığı suç bakımından Isslâm ceza hukukuna aykırıdır. 6 numaralı hükümde gördügüimüz malî cezá ise yukarda görmüş̧ olduğumuz diğer bütün malî cezalar gibi İslâm ceza hukukuna uymamaktadır.

FK. ve SK. 28'de yolculuk sirasinda yol üzerindeki yerlerden zorla ekmek veya yoğurt alanların Tazir edilmeleri ve bunlardan sopa bașına bir akça para cezası alınması emredilmiştir. Gene izah edilmesi güç bir sebeple SK.sinde bu suçu ișliyenler Zimmî iseler para cezasının yarısını ödiyecekleri yazılmıştır. Yol üzerindeki yerlerde oturanları gelip geçenlerin ihtiyarì hareketlerinden korumak için konulmuș olan bu hükümlere karşılık MK.nin 2 numaralı hükmü de yolculàrın emniyetini sağlamak ve yolları korumakla mükellef olan Derbend muhafizlarının ihmallerini cezalandırmak için konulmuștur.

FK. ve SK. 27'de sahipsiz yerlerde sığır, at veya koyun bulanlardan bu hayvanlarm sahiplerini buldurmak için gereken tedbirleri almıyanlara màlî durumlarına göre para cezası tayin edilmiștir.

SK.nin 28-32 numaralı hükümleri bașkasının ekinine giren hayvanların sahiplerine verilecek cezaları tayin etmiștir $\mathrm{ki}$ bu, ceza hukuku dișında kalan madì tazminatdan bașka, miktarları hayvanların cinsine göre değișen sopa ve para cezalarından ibarettir.

Bu suretle Osmanlı kanunnamelerindeki İslâm ceza hukukuna aykirı hükümleri bitirmiș oluyoruz. Bu hükümlerin menșei hakkındaki bilgilẹrimiz ne yazıktır ki çok azdır. Ancak şimdiden bunların Türklerin örf ve âdet hukukundan doğmuș olduklarını ve Osmanlılardan önce Selçuklar zamaninda yürürlükte olduklarını kesin olarak söyliyebiliriz. Nirekim 884 - 921 ylliarı arasında hüküm sürmüș olan 'Alâ üd-Devle Bey'e izafe edilen kanunnamede (58) incelemiş olduğumuz hükümlerin birçoklarının aynını veya az değișik șekillerini görmekteyiz:

57) Bk. FK. 5

58) BK. Omer Lutrî Barkan: XVI, asirlarda Osmanlı Imparatorluaunda ziraî ekono minin hukuki ve Malí esasları. I. Cilt. : Kanunlar: Ist. 1943. S. 119 v. öt. 


\section{'ALA ŨD - DEVLE BEY KANUNU}

1. Evvelâ bir kimesne kim yol kesüb haramilik etse siyaset oluna.

2.- Ve her kim at oğrılasa veyahut katır oğrlasa eli kesilmezse on sekiz altın alına eğer sagir oǵrılasa kat-i yed olmazsa ondört altun alina ve bu mezkûrlara her kim ki şerik olsa eğer üç ve eğer dört kimesnedir her birinden tamam cerime alına ve koyun ve keçi oğrisından beș altın alına.

3.- Eğer bir kişi iki at ya iki deve ya iki sığır ya iki katır ya iki koyun veyahut ikiden artık bir def'a ya iki def'a serika eylese her davar başına mezbur tamam cerime alına üçten artık serika eylese bir def'a yine üç davar cerimesi alına.

4.- Ve kovan ve saban demüri ve çul ve bukağu ve özengi ve eğer ve bunlara mümasil nesne serika eylese bahası on akça ola beş altín alina.

5.- Ve her kim ev yarsa kat-i yed olmazsa yirmi altın alına ve éğer kapu yarsa kat-i yed olmazsa on beş altın alına.

6.- Ve her sarikin ki kat-i yed ola eğer aynı ile' serika itdüğü davar durursa alınub sahibine virile durmaz ise tazmin olunmiya.

7.- Her kim oğrıyi oğrılık iderken ursa öldürse suçlu olmaya.

8.- Her kim ki oğrılıkla müttehem ola andan bir nesne sezseler örfen tazmin itdüreler.

9.- Bir kimesne gice ile bir eve girse girmesi ma'hud değïl ise örfen ev sahibi ursa öldürse suçlu olmiya.

10.- Her kim zinâ eylese şer' ile örf ile subut bulsa ergen ise had olmaz ise on üç altın alına evlü ise recm olmazsa on beş altın alına.

11.- Eğer nişanlusuna duhul itse zinâ gibidir amma varsa duhul itmese beş altın alına.

12.- Her kim ki eve girse zina kasdina yahut yapıșsa öpse ol öpülenin rı́ası olsa zina cerimesi alına eğer gücile ise girdügi ya öpdigü veya yapıșdığı beş altın alına eğer kız öpdiyse andan zina ceremi alına eğer kız rıza ile öpdürse atasından ya kardașından nesne alınmaya amma evidir zina ceremi iki canibden bile;

13.- Eğer bir kimesne mahremini ecnebi ile mülâ'abe ve mübașere iderken görse anları öldürse kanlu değildür örfen günahlu oldu deyụ nesne alinmaya.

14.- Bir kimesne dâyim pezevenklik itmek âdeti olsa yüzüne kara dürtüp rüsvâ-i âm ideler burnunu ve kulağını keseler eğer değül jse beș altın alına. 
15.-.. Ve bir niçe kişi ev basub kuz kapsalar hel bivinden varanın on beş altin alına eğer âdem cerahat eyleseler şer'an diyeti alınub sahibine vireler ve eğer oğlan çekseler arıdalar ve illâ yirmi dört altın alına. Eğer muhabbet bile itse iki tarafa zina haddin uralar ve illâ zina ceremi her birinden alina.

16. - Eğer kız çeküp alub gitdüginden sonra nihâk itse nikâh fasiddür ta'zir ideler meğer ki velisi câiz göre yine bunclayın rızası ile uydursa nikâh itse velisi tecviz itmese küfür oldığı (kiufüv olmadığı) cihetden te'arruz caizdir.

17. - Ve oğlanciklar mübadele eyleseler ziyade tevci' idüp tazir ideler amma cerem alınmaya.

18. - Her kim kan eylese katle müstahak ise kısas oluna ya sulha ya diyete müstahak ise diyetden galyrı otuz altin cerem alina.

19. - Eğer diș çıkarsa dişi çıkan savaşa sebeb olsa ser'an lâzın olan diyetin nısfı alalar ve diș çıkarandan sekiz altın alalar.

20.- Eğer barmak sisa baș yarsa tașıla yahud ağacıla yahud bir katı nesne ile ursa beş altın alına birini bașını yarılana vireler.

21.- Ammâ eli ile urub uvatsa ya yakasın yırtub saçin sakalın yolsa otuz akça alına.

22.--Kara bere ve sıyruk ki taşıla ya ağacıla olsa yaruk hükmi gibidir eğer bunlar el ile ya tırnağıla olsa burun kanamak gibüdür.

23. - Her kim kol sisa yahud ayak sisa yahut bir uzvinı sindursa döşeğe düşer eylese kazancından kaç gün: kalsa betâlet zamanın on dört altın alına ve hatayla eylese bes altın alma.

24.- Ve göz çlkaran diyetin sahibine virüb on dört altın alına ve hatayıla itse beş altın aỉna.

25. - Ve eğer kulağın urub tașla ya ağacila sağır eylese ve burnın kesse hükmi göz hükmi gibüdür sșer'an diyet alduktan sonra kasden eylese ondörder altın alına değül ise beș altın alına.

26. - Eğer bir katı nesne ile urub kara bere itse bir altın alına ve ei ile yumruğile ve depme ile itse otuz akça alına saç sakall yolsa öyle oluna eğer kılıcıla ya bıçağıla ya okula urub itse on altın alına.

27.- Eğer öldứrmek ya paralamak kasōina kovsa kurtulsa dönse paralasa ya kolun ya parmağın sıysa hiç nesne yok.

28.- Eğer kılıc ya biçak çıarsa ya ok gizlese çalmak ve urmak kasdına çalsa ikiyüz akça alına eğer calub kılıcıla veya okıla ya biçakla döşeğe düşürse on dört altın alına eğer çalsa kesmese olmuş gibüdür on dört altin alina 
29. - Eğer savaşa sebeb olan paralansa şer'an lâzım olan diyetin yarısı alına.

30.- Eğer sayıcıdan koyun gizleseler koyun başına bir akça alına. Eğer tavuk ve bostan ve yemiş oğrılasa bahasin issına virüb yirmi akça alina.

31.- Ve ölçümden tahıl gizlese kabıyla alalar.

32.- Ve fellah sipahiye el kaldirmaya kaldursa on altın alına.

33.- Eğer davar tahila girse beş ağaç urup beș akça alına.

34.- Ve kaz oğrisindan otuz akça alına.

Eğer bir kimsenin kapısından ya bacasından baksalar kırk akça alina.

Eğer avamdan ise şer'le isbat itdüreler değül ise havasdan dindar kimesne ise sözüne inanalar ve a'vamđan olan yalan çıkarsa beş altın alina veyahut dili kesile.

35.- Ve eğer nügisin eksik dartsa satduğundan dirhem bașina bir akça alina ve hadd dahi uralar.

36. - Ve dam ve hüyüg yıkup ziyan itse sahibine ziyanın eââ ịdüb beș altın alına.

37.- Eğer sipahi kolayına giderken raiyeti incüdüb döğse sipahinin hakkından geleler.

38.- Eğer yalan yire kasdıla tanıkliğı zâhir olsa veya and içse yưzüne kara dürtüb beş altın cerem alına.

39.- Ve eğer ağza söğse Hadd uralar otuz akça alına ve suci içen ayıldıktan sonra seksen akça alına veya seksen ağaç uralar.

40.- Eğer muhsan ya muhsane bühtan itse zinâ gibüdür seksen ağaç veya seksen akça alına.

41.- Eğer bir tayife ev basmağa varsa ol cemaatten kimeki yarak dokunsa suçu olmaya meğerki öldüreler yahut paralayalar ve ev basanlardan ikişer altın alına.

42.- Ve eğer kız deyü alsalar delük çıksa özr-i șer'î ile zayil oldı ise mehri tamam vireler eğer özge cihetle zayil oldı ise nısıf mehir alalar.

43. - Eğer bir kimesnenün̆ serika èttiği on akçadan akal değil ise eli kat' olmayub bir altın alına șer'an iki müslüman-i âdil şehadetiyle mevkuftur.

44.- Eğer bir kimesne ağıza söğse kadı huzurunda hadd uralar.

45. - Ve koyun bacm satandan ve alandan birer osmanî alına.

46. - Ve her nikâhdan kazıaskere sekiz akçe ve mirasdan yüzde iki buçuk akçe alına. 
47.- Ve kan cerimesi üçyüz pare ve oğrı cerimesi yüz elli pare ve ok ve kllıc cerimesi yüz elli pare ve kız ve avrat çekilseki ceken evlü ola üçyüz pare ve bir mahalleye bir mahalleden kimesne gelüh ev bassa âdem bașina kırk pare ve kul ve at ve deve ve katır yavası vakî olsa Zülkadir beğleri tasarrufundadir.

48. - Amma kız ve avrat çekilse ve evlü kị̧i çekse yüz elli pare ve 'azab kimse çekse ve hamile itse üçüz pâre ve bir kiși nişanlusuna varsa yüz pâre ve baș yaruğuna elli pâre ve diş çıkarana yüz yirmi pare göz çıkarandan yüz elli pare ve kara bere cerimesi on iki pare ve kol sinmak cerimesi seksen pare ve at ve deveden ve kuldan ve katırdan yava vakî olsa ve boylara kethüda nasbetmek hususunda bu cümlesi boybeğinündür.

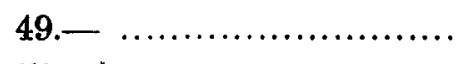

50 . -

51:- Ve bu kanunnamenin hükmüne muhalefet idenler suçlıdır 'itaba müstahak olurlar șuyle bileler sûret-i kanunname-i 'Ala üd-Devle beğ nukile 'anil asl-i bilâ tagyir-i velâ tebdilin.

Konumuzun dișına çıkmamak için bu kanunnamenin hükümlerini ayrı ayrı incelemiyeceğiz. Ancak henüz suçlular malî durumlarına göre ayrilmadıkları halde Hadd. Kısas, Diyet ve Tazir cezalarıyla yetinilmesi gereken birçok yerlerde bu kanunname hükümlerine göre de para cezası alındığı, burun, kulak(59) dil(60) kesme gibi İslâm ceza hukukunda bulunmiyan cezalara yer verildiği ve bu hükümlerin birçok bakımlardan Osmanlı kanunnameleri hükümlerine benzediği açıkça görülmektedir.

Bu hükümlerin İslâm olmadan önce de Türkler arasında yürüriükde, olup olmadiğı, Müislüman Türkler tarafından ilk önce ne zaman uygulandığı ve suçluların malî durumlarına göre ayrılmaları yoluna ne zaman gidildiği ancak ilerdeki çalıșmalardan sonra aydınlanabilecektir.

\section{Doç. Dr. Coşkun ÙÇOK}

\section{BLBLIYOGRAFYA}

Kur'an

Tevrat

Ahmed Lutfí: Mir'at-i adalet.

59) Bk. 14. numaralı hüküme

60) Bk. 34 . Numaralı hüküme. 
Bosna Kanunnamesi: Glasnik Zemaliskog Mużeja u Bosni i Hercegovini, XXXVIII., 1916, 3/4. S. 448 ve yt.

Dürer tercümesi.. İstanbul.

Fetava-i Feyziyye. Istanbul.

Handwörterbuch des İslam. Leiden. 1941.

Hoca Emin Efendi Zade Ali Haydar: Dürer ül-Hükkâm șerh-i Mecellet ül-Ahkâm. İst. 1330.

Kànunî Sultan Suileyman Kanunnamesi: TOEM., 16 - 19 saylara ek.

Kinmizade mecmuasi.

Kraelitz -Greifenhorst: Fatih Kanunnamesi. MOG., I., 1921.

Kresmarik, Johann: Beitraege zur Beleuchtung des islamitischen Strafrechts, mit Rücksicht auf Theorie und Praxis in der Türkei. ZDMG., LVIII. 69-113, 316-360; 539-581.

Maverdî: El-Ahkâmüssultaniyye. Fagnan terc. Alger. 1915.

Mehmet Zihni: Kitab ül-Tahare.

Mevkufat. Istanbul. 2. cilt.

Ömer Hilmi: Miyar-i adalet. Istanbul 1301.

Redd ül-Muhtar. Misir. 7 cilt.

Tercüme-i Tahtavî: İstanbul. 8 cilt. 